\title{
Medisinsk fødselsregister i yrkesepidemiologisk forskning
}

\author{
Ågot Irgens ${ }^{1}$, Karl-Christian Nordby ${ }^{2}$ og Petter Kristensen ${ }^{2}$ \\ 1) Yrkesmedisinsk avdeling, Haukeland Universitetssykehus, Bergen \\ 2) Statens Arbeidsmiljøinstitutt, Oslo \\ Korrespondanse: Ågot Irgens, Yrkesmedisinsk avdeling, Haukeland Universitetssykehus, 5021 Bergen \\ Telefon: 55973882 telefax: 55975137 e-post: aagot.irgens@helse-bergen.no
}

\begin{abstract}
SAMMENDRAG
Medisinsk fødselsregister (MFR) har både helseforskning og helseforvaltning som formål. Ved etableringen av MFR i 1967 fikk vi i Norge en unik mulighet til å studere fødselsutfall knyttet til yrket, over lang tid og i spesielt eksponerte grupper. Det er en styrke at MFR inneholder informasjon om alle fødte, men en ulempe at blant annet opplysninger om spontanaborter og ventetid til graviditet mangler. Tidligere yrkesepidemiologiske studier har vært gjennomført ved å koble MFR-data til yrkesdata fra andre kilder som yrkeskohorter, fagforeningslister, og offentlige registre som Landbrukstellinger og Folke- og boligtellinger. Vi har gitt en oversikt over studier med fokus på definisjon av yrke- og yrkeseksponering. Vi avslutter med å se på utfordringer ved fremtidige yrkesepidemiologiske studier, muligheter for å øke kvalitet og validitet, samt å peke på fremtidsmuligheter som ligger i yrkesepidemiologi ved bruk av MFR. Vi fokuserer spesielt på kilder der yrkes- og yrkeseksponerings-data kan finnes, men også på studier der opplysninger om genetikk kobles mot arbeidsmiljø, samt studier med opplysninger fra bestemødrenes arbeidsmiljø. Til tross for problemer knyttet til slike studier, har vi i Norge gode muligheter til å gjennomføre dem siden norske overvåkningssystemer er i stadig utvikling og bioteknologisk kunnskap internasjonalt er økende. Dette i tillegg til et utstrakt samarbeid mellom de nordiske land, kan være veien å gå.
\end{abstract}

Irgens Å, Nordby K-C, Kristensen P. Medical Birth Registry of Norway in occupational epidemiologic research. Nor J Epidemiol 2007; 17 (2): 131-139.

\section{ENGLISH SUMMARY}

The aims of the Medical Birth Registry of Norway (MBR) are research as well as health management. By the establishment of MBR in 1967 we got a unique opportunity to study birth outcomes related to occupational exposure during a long time period and within groups. It is a virtue that MBR has registered information on all births, however, a disadvantage is that information on early spontaneous abortions and waiting time to pregnancy are missing. MBR data were linked to occupational data from other sources in published epidemiological studies related to occupation. Such sources are occupational cohorts, lists from labour unions and public registries as agricultural and horticultural censuses and population censuses. The former studies are reviewed, focusing on the definition of occupation and occupational exposure. We discuss challenges in future occupational epidemiological studies and point out some future challenges and ways to improve quality and validity. We have further emphasised on potentials in occupational epidemiology using MBR, as well as on sources where occupation and occupational exposures can be found, geneworking environment interaction studies and studies where we allow for grandmothers' working environment as well. In spite of problems attached, in Norway we have the possibilities to carry out such studies due to expansion of Norwegian systems of surveillance, and since the knowledge in biotechnology internationally is growing. This, in addition to extensive co-operation between the Nordic countries may be a useful approach in future studies.

\section{INNLEDNING}

Medisinsk fødselsregister (MFR) har både helseforskning og helseforvaltning som formål. Registeret skal bidra til å avklare årsaker til og konsekvenser av helseproblemer i forbindelse med svangerskap og fødsel, skal overvåke forekomster av medfødte misdannelser og spesielt oppdage så tidlig som mulig eventuelle hyppighetsøkninger.

Med etableringen av Medisinsk fødselsregister i 1967 fikk vi i Norge en unik mulighet til å studere fødselsutfall, over tid, innad i spesielt eksponerte grupper og til å se på sammenhenger mellom fødselsutfallet og andre forhold. MFR har informasjon om barnet og mor. Opplysning om hvem som er faren finnes i de fleste fødselsmeldingene. Far er enten oppgitt av mor eller, blant gifte, identifisert som ektemannen. 


\section{Styrker og svakheter ved MFR i epidemiologiske studier}

I motsetning til misdannelsesregistre som finnes i flere land, inneholder MFR opplysninger om alle fødte i Norge. De data som er samlet inn er i stor grad de samme i løpet av hele perioden, selv om innholdet er noe utvidet etter at et nytt meldeskjema ble tatt $\mathrm{i}$ bruk $\mathrm{i}$ 1998. Ved hjelp av fødselsnummeret er det $\mathrm{i}$ forskningsøyemed mulig å gjennomføre fullstendige koblinger mellom MFR og andre datakilder. MFR-data kan derfor ordnes i datafiler der mor er analyseenheten med opplysning om alle hennes barn, eller der generasjoner er koblet (bestemor-mor-barn). Det er også en styrke at MFR har pålitelige og nær fullstendige data for mange perinatale utfall som fødselsvekt, svangerskapsvarighet, perinatal død m.m.

Fødselsutfallet registreres mens mor er på fødeinstitusjonen eller mens barnet eventuelt er $i$ en neonatalavdeling. Misdannelser som oppdages senere, vil ikke tas inn i fødselsmeldingen. Misdannelser ble kodet i ICD8-kodeverket frem til 1999, da ICD10-koder overtok. Hvor komplett rapporteringen er, vil avhenge av type misdannelse. Alvorlige og synlige morfologiske forandringer registreres i større grad enn mindre synlige misdannelser som for eksempel hjertefeil. Fra 1999 år har MFR innført en separat registrering av diagnoser fra neonatalavdelingene og en egen registrering av diagnoser fra nemndbehandlede søknader om abort. Denne registreringen vil kunne korrigere for manglende og feilaktig rapportering av misdannelser. Men heller ikke i de seneste årene kan tilstander som oppdages etter første leveår bli registrert i MFR. Dette kan for eksempel berøre registrering av psykisk utviklingshemning.

Feilklassifisering av misdannelser kan være et problem. Mer detaljert opplysning om hver enkelt misdannelse kan vi få i fremtiden gjennom rene misdannelsesregistre. Et eksempel på dette er hjertefeilregisteret BERTE som i 1989 ble etablert på Rikshospitalet.

MFR inneholder informasjon om alle fødte etter 16. svangerskapsuke. Selv om dette er utvidet til fødte etter 12. uke fra 2001 da ny forskrift for MFR (1) ble innført, vil det ikke være mulig å studere tidlige spontanaborter ved hjelp av MFR.

\section{Yrkesepidemiologi}

MFR inneholdt i starten ingen spørsmål knyttet til mors yrke og yrkesaktivitet. MFR's nye meldeskjema fra 1999 inneholder imidlertid spørsmål om yrkesaktivitet (Ikke yrkesaktiv, yrkesaktiv heltid, yrkesaktiv deltid) og i et fritekstfelt registreres mors opplysninger om yrke og bransje dersom mor samtykker til dette. Så langt har man derfor koblet opplysninger om yrke og yrkeseksponering fra eksterne kilder til MFR ved hjelp av fødselsnummeret. Kildene kan være eksponeringsdata fra bedrifter, fagforeningslister, og opplysninger som det offentlige har samlet inn, for eksempel Landbrukstellinger og Folke- og Boligtellinger.

\section{YRKESEKSPONERING OG FØDSELSUTFALL FRA MFR. Problemstillinger - HVA ER PUBLISERT?}

Vi har klassifisert problemstillingene etter kilde for yrkeseksponering og indikatorer. Under Yrkesspesifikke kohorter presenterer vi studier med individuelle eksponeringsopplysninger og eksponering som er karakterisert på gruppenivå. Under Registerstudier viser vi studier der yrkesopplysning ble hentet fra Statistisk sentralbyrå. Flere yrkesstudier med pasient-kontrolldesign er gjennomført internasjonalt. Selv om enkelte norske pasient-kontroll studier har inkludert yrkes- og eksponeringsopplysninger, har dette med et par unntak ikke vært hovedfokus i studier hvor MFR-data inngår.

\section{Yrkesspesifikke kohorter}

Barn av flygende personell

Store bedriftsarkiver med eksponeringskartlegging av arbeidsoperasjoner over tid er et godt utgangspunkt for yrkesepidemiologiske studier. En slik tilnærming, med kobling mot MFR, ble brukt for å studere fødselsutfall hos barn av mannlige flygere $(\mathrm{N}=2356)$ og kvinnelig kabinpersonell ( $\mathrm{N}=2512)$ (flyvertinner) (2). Man testet hovedhypotesen om økt forekomst av Down syndrom hos flyvende personell som utsettes for kosmisk stråling, samt om det var økt forekomst av ni andre fødselsutfall. Et norsk flyselskap (SAS) hadde opplysninger om flygernes aktivitet hvert år fra 1960 - timer i luften, per flytype (flyhøyde) og per flyrute. Ved hjelp av dataprogrammet CARI kunne individuell kosmisk stråledose beregnes per år og kumulativt. For flyvertinner hadde man bare opplysninger om antall dager med lisens per år og totalt. Dette ble brukt som erstatning for yrkeseksponering med stor fare for feilklassifisering siden grad av eksponering kunne variere mye. Både hos flygere og flyvertinner så man en tendens til $ø \mathrm{kt}$ risiko for å få barn med Down syndrom. Ingen økt risiko ble vist for de øvrige utfallene som ble studert.

Barn med fedre i grafiske fagforeninger

Opplysninger kan innhentes via medlemslister fra fagforeninger. Disse kan inneholde opplysninger om når og hvor mor eller far var ansatt, samt detaljert yrkesklassifisering. Grafiske fag egner seg i prinsippet godt for slike studier fordi det tradisjonelt har vært skarpt skille mellom arbeidsoppgaver for de ulike yrkeskategoriene, og fordi disse kategoriene var godt bekrevet. Hypoteser knyttet til fars eksponering forut for konsepsjonen og fødselsutfallet ble undersøkt $i$ en studie der opplysninger om yrkeskategorier fra Oslos grafiske fagforeninger ble koblet til MFR (3). Basert på detaljert yrkesklassifisering (69 kategorier) ble fedrene kategorisert etter eksponering for bly og løsemidler. Det ble observert økt risiko for tidlig fødsel blant barna dersom far var eksponert for løsemidler, og forfatterne diskuterte om dette kunne skyldes confounding av røykevaner eller andre faktorer knyttet til sosial posisjon fordi de løsemiddeleksponerte gjennomgående var 
ufaglærte. Undersøkelsen omfattet 6251 fødsler i MFR og var for liten til å gi robuste resultater for spesifikke misdannelser.

\section{Barn av kvinnelige Postgiroansatte}

Med økende bruk av dataterminaler var skadeeffekter av eksponering under graviditet et omdiskutert tema på 1970-tallet. Dette var utgangspunktet for en studie av MFR-registrerte fødsler 1967-84 til 2910 kvinnelige Postgiroansatte (4). Prevalensene av perinatal død, lav fødselsvekt, førtidig fødsel og misdannelser for i alt 1820 fødsler meldt til MFR ga ikke støtte til hypotesen om skadelige reproduksjonseffekter av elektromagnetiske felt.

\section{Barn av kvinner i plastindustrien}

I en svensk-norsk pasient-kontroll studie av fødselsutfall blant kvinner i plastindustrien inngikk 288 fødsler $\mathrm{i}$ den norske delen (5). Pasientkategoriene var perinatalt døde, barn med misdannelser og fødselsvekt $<2000$ g. Eksponeringsdata ble samlet fra arbeidsgiverne. Studien var liten og det var ikke klare assosiasjoner med ulike typer plastproduksjon (herdeplast, termoplast).

\section{Barn av kvinner ansatt $i$ kjemiske renserier}

Reproduksjonsskader blant kvinner som ble eksponert for perkloretylen i kjemiske renserier ble undersøkt i en nordisk pasient-kontroll studie (6). Den norske delen av denne studien var basert på fødsler blant kvinner som hadde vært ansatt minst en måned $\mathrm{i}$ renserier mellom 1972 og 1984. Studien gikk ut på å estimere assosiasjoner mellom skadelige fødselsutfall og indikatornivå av perkloretyleneksponering. I den norske del av studien ble i alt 455 fødsler registrert, derav syv barn med fødselsvekt $<1500$ g og syv barn med misdannelser. Eksponering var basert på opplysninger fra arbeidsgiver i den norske del av studien. På grunn av nasjonale forskjeller kunne ikke data fra de nordiske land analyseres samlet, og resultatene måtte rapporteres for hvert land. Det mest signifikante funnet var økt forekomst av spontanaborter i Finland.

\section{Kobling mellom MFR og SSBs landbrukstellinger}

Det finnes eksempler på at eksponeringsindikatorer finnes i offentlige registre. Et eksempel på en slik mellomting mellom yrkeskohort og et nasjonalt register er SSBs obligatoriske landbruks- og hagebrukstellinger som danner et viktig grunnlag for offentlig statistikk og tilskuddsordningene i norsk landbruk. Data i tellingene gir detaljert informasjon om aktivitet på brukene. Disse opplysningene kan brukes som utgangspunkt for å lage eksponeringsindikatorer, ikke bare for eier av bruket, men også ektefelle og barn siden norsk landbruk er dominert av familiedrift. I de refererte studiene er de fem tellingene mellom 1969 og 1989 brukt. I flere av studiene er det også brukt klimadata fra Norsk Meteorologisk Institutt. Dette gjelder i første rekke de daglige tørråtevarslene fra lokale værvarslingsstasjoner, som har vært et viktig element i norsk plantevern gjennom nesten 50 år. Kobling av disse data mot MFR har vært en viktig del av to doktorgradsarbeider $(7,8)$.

\section{Generelt}

Generelt var perinatal helse hos barn av norske landbrukere lite forskjellig fra andre fødte i Norge. Sammenlignet med barn født av andre i jordbrukskommuner hadde bondebarn en fordelaktig fordeling av svangerskapsvarighet og fødselsvekt (9). Perinatal dødelighet var lik i de to gruppene, men andel av sene aborter (16.-27. uke) var høyere hos bønder, og spesielt de fra kornbruk. En av hypotesene var at perinatal død er assosiert med foreldres eksponering for plantevernmidler.

Studiet av misdannelser i landbruksbefolkningen hadde hovedhypotesen at foreldres eksponering for plantevernmidler var assosiert med misdannelser i sentralnervesystemet, leppe-ganespalte, reduksjonsdeformiteter og genitaldefekter hos sønnene (10). Det ble funnet en moderat økning av sentralnervøse misdannelser. Økningen var sterkest ved bruk av plantevernmidler på gårdsbruk med fruktdyrking eller veksthus.

\section{Sammenheng mellom indikatorer på mykotoksin-} eksponering og utfall registrert $i$ MFR

Selv om enkelte soppgifter er vel dokumenterte årsaker til abort og fødselsinduksjon, hadde plantevernmidler vært i fokus i studier basert på denne koblede kohorten. Assosiasjonen mellom senabort og kombinasjonen kornbruk/fuktig klima førte til en endring av innretningen i hele prosjektet, med hypoteser knyttet til immunologiske effekter av soppgifter eller andre agens (11).

Funnet av sammenhengen mellom kornbruk og senabort ble fulgt opp i en studie hvor den modifiserende effekten av mors reproduksjonshistorie ble analysert i et materiale (12). Dette ble organisert i likhet med Skjærvens og medarbeideres (13) analyse av selektiv fertilitet $\mathrm{i}$ totalbefolkningen. Mor ble her valgt som analysesenhet for å kunne følge hennes reproduksjonshistorie (12). For totalt 45969 bønder med første fødsel 1967-1981 ble de påfølgende fødslene og perinatal mortalitet observert (12). Tidligere prematur fødsel, var determinant for senere fødsler $\mathrm{i}$ annet trimester, og dette var spesielt markant for kvinner på kornbruk og i sesonger med mange tørråtevarsler (12).

Kohortstudier har den fordel at man kan studere mønstre blant flere utfall som kan ha etiologiske eller patogenetiske likhetstrekk. Mistankene om immunologiske eller hormonelle virkninger, førte til analyser av flere utfall blant familier ved kornbruk: kreft (livmor, eggstokk, bryst, testikkel, prostata) og genitalmisdannelser (14). Eksponeringsindikatoren (kombinasjon kornbruk og tørråtevarsler) var assosiert med kreft i livmor, eggstokk og bryst hos bondekoner, og spesielt for premenopausale kvinner med barn, men ikke for noen av utfallene hos mennene eller barna.

Indikatorer på immunologiske effekter har også vært undersøkt for andre effekter i MFR. I en slik 
studie (15) ønsket forfatterne å teste hypotesen at immunomodulerende substanser, som mykotoksiner, endotoksiner eller plantevernmidler, påvirker risiko for pre-eklampsi. Dette var basert på at forstyrrelser i immunsystemet er involvert i patofysiologien ved preeklampsi. Eksponering for immunomodulerende substanser som indikert ved kornproduksjon, husdyrhold og tørråtevarsler, var moderat assosiert med preeklampsi, og resultatene kunne således støtte hypotesen.

Forekomst av dizygote (DZ) tvillingfødsler har økt på verdensbasis de siste tiårene som en konsekvens av assistert befruktning, men miljøforurensninger har også vært mistenkt som årsak. Trender for tvillingfødsler ble også undersøkt i landbruksbefolkningen, og assosiasjonen mellom kornproduksjon under dårlige klimatiske betingelser som forårsaker soppvekst og forekomst i DZ tvillingfødsler ble analysert (16). Eksponeringen influerte lite på forekomst av DZ fødsler.

\section{Eksponering for spesifikke plantevernmidler og MFR- utfall}

Bruk av plantevernmidler i Norge er knyttet til godkjenningsordninger. I visse tilfelle er det derfor mulighet for å anslå om midlet har vært anvendt på det enkelte bruket, og i tilfelle når. Dette har vært brukt $\mathrm{i}$ landbrukskohorten i studiet av årsaker til bestemte misdannelser.

Soppmidlet mankozeb har vært mistenkt å kunne forårsake skjoldbrukkjertelkreft og nevralrørsdefekter. Hypotesen at mankozebsprøyting på gården fører til økt risiko for nevralrørsdefekter blant barn av landbrukere, ble testet i landbrukskohorten (17). En moderat assosiasjon ble observert mellom nevralrørsdefekter og potetproduksjon, samt når far arbeidet mer enn 500 timer per år på bruket.

Et annet soppmiddel som har vært mistenkt årsak til bestemte misdannelser er benomyl. Mistanke om at benomyl er årsak til manglende utvikling av øyeanleggene kunne derfor vurderes blant landbrukere. I et brev til British Medical Journal konkluderte forfatterne at ingen sammenheng kunne påvises (18).

\section{Deskriptive studier og metodestudier med utgangs- punkt i landbruksbefolkningen}

Flere av publikasjonene har bidratt til kunnskap om reproduksjonsmønstre i landbruksbefolkningen. Landbrukere fikk flere barn enn andre i Norge (12). Perinatal død økte sannsynligheten for at bøndene, i likhet med befolkningen for øvrig, påbegynte en ny graviditet, men denne selektive fertiliteten var mindre dominerende enn i den generelle befolkningen på grunn av høyere generell fertilitet.

Mors reproduksjonshistorie er viktig som kovariat $i$ studiet av sammenheng mellom yrkeseksponering og reproduksjonsutfall. Et slikt eksempel er betydningen av mors tidligere fødselsutfall for assosiasjonen mellom mykotoksinindikatoren i kornbruk og prematur fødsel (12). I MFR kan mors historie finnes i tidligere fødselsmeldinger og knyttes til senere fødsler i filer med mor som analyseenhet (12). Alternativet er ofte å bygge på mors egne angivelser om tidligere fødsler $i$ tverrsnittstudier. MFR inneholder mors egne opplysninger om tidligere fødsler også, og dette tillater en sammenligning mellom longitudinelle data og tverrsnittsdata. Imidlertid kan mors angivelser eller definisjoner av tidligere fødsler være upålitelig i forhold til dødfødte, aborterte etc.

Mors reproduksjonshistorie basert på de faktiske fødselsmeldingene og retrospektiv informasjon (basert på jordmors intervju av mor ved senere fødsel), ble sammenlignet $i$ en valideringsstudie av landbruksbefolkningen (19). Samsvaret i opplysninger om tidligere dødfødsel var ganske bra. Det var likevel indikasjoner på at bruk av retrospektive data kan skape alvorlig resultatskjevhet $\mathrm{i}$ studiet av sammenhengen mellom yrkeseksponering og reproduksjonsutfall. Den sterke interaksjonen mellom mykotoksinindikatoren og prematur fødsel som ble funnet når tidligere dødfødsel var basert på longitudinelle data (12) forsvant helt når retrospektive data ble brukt (19). Forklaringen var at retrospektive data ofte ikke samsvarte med tidligere fødselsmeldinger når mor kom inn med en problemfødsel (som annen-trimesterfødsel er) (19). Årsaken kan være at jordmors nedtegning i fødselsmeldingen ikke er like god ved øyeblikkelig hjelp, eller at mor lar være å opplyse om tidligere dødfødsel nå hun igjen står i fare for å oppleve dette.

\section{Registerstudier - Kobling mellom MFR og SSBS Folke- og boligtellinger}

Flere norske studier bygger på en kobling mellom MFR og data fra Statistisk sentralbyrås Folke- og bolig tellinger (FoB).

Bjerkedal (20) gjennomførte den første studien av yrke og fødselsutfall hvor MFR ble brukt. MFR-data 1970-73 ble koblet til opplysninger om mors yrke i FoB 1970 for mer enn en kvart million fødsler. Det ble funnet at yrkesaktive kvinner hadde litt høyere prevalenser av lav fødselsvekt, misdannelser og perinatal død enn ikke yrkesaktive, mens prevalensen av førtidig fødsel var litt lavere (20). En nærmere studie av misdannelser blant førstefødte viste at blant de yrkesaktive kvinnene var prevalensene høyest for teknisk arbeid (ratio 1,46) og sykepleiearbeid (ratio 1,32) (21). Disse to gruppene inneholdt laboratoriepersonell og operasjonssykepleiere, og funnene ble derfor knyttet opp til tidligere publiserte studier om overrisiko i disse yrkene.

Senere er det gjennomført flere koblinger mellom MFR fra ulike tidsperioder og FoB fra 1970, -80, eller -90. Noen av studiene har brukt yrkesinformasjon fra en av foreldrene, andre fra begge. De senere studiene har i større grad hatt som mål å studere hypoteser om økt risiko for uønsket fødselsutfall på grunn av yrkeseksponering, - på tvers av landegrenser, når eksponeringen er endret over tid og hos yrkesgrupper med ulik grad av eksponering. 
Resultater fra tidligere studier - bekreftes disse med norske data?

I noen av registerstudiene ble MFR-data fra 1970-93 supplert med FoB 1970, -80 og -90 med opplysninger om både mor og fars yrke, bransje og utdannelse. Siden FoB er gjennomført hvert tiende år, valgte man å benytte FoB-opplysninger fra tellingen som lå forut for fødselen. Dette vil medføre en økende grad av feilklassifisering med økende tid fra en telling. Et tilleggsproblem er at FoB 1990 var ufullstendig. Resultatene fra alle disse analysene er samlet i rapporten Yrke og reproduksjonsutfall (22).

Studien (23) ønsker å etterprøve resultater om økt risiko for misdannelser hos barn av fedre i spesielle yrkesgrupper samlet i boken Male-Mediated developmental toxicity (24). Studienes design og størrelse varierer mye. Feilklassifisering av misdannelse og yrke kan forekomme, både $\mathrm{i}$ de tidligere studiene og i det norske materialet. I tillegg kan man ikke alltid sammenligne yrkeseksponering på tvers av landegrensene. Også for de norske dataene hadde sønner av bilmekanikere økt forekomst av hypospadi, det ble sett en tendens til økt forekomst av spina bifida hos barn av malere, og klumpfot hos barn av trykkeriarbeidere. De øvrige hypotesene som ble testet ble ikke bekreftet. Til dels kan dette skyldes at yrkesgruppene var så små at den statistiske styrken ble lav, men også for store yrkesgrupper som lærere, sjåfører og yrker relatert til landbruk, elektrisitet og salg kunne ikke de oppsatte hypotesene bekreftes.

\section{Fødselsutfall for spesifikke yrkesgrupper og yrkes- eksponeringer}

\section{Blyeksponerte foreldre - fødselsutfall}

Bly er et kjent teratogen, men har grad av blyeksponering vært et problem $\mathrm{i}$ arbeidslivet $\mathrm{i}$ Norge? Det ble det laget en eksponeringsmatrise tilpasset norske forhold på grunnlag av yrker i et kriteriedokument for organisk bly (25).

Opplysning om yrke, næring og bosted måtte brukes for å velge ut eksponerte grupper. Eksempelvis ble følgende grupper klassifisert som høyt eksponert for bly (26):

- Yrkestitlene hytte- og smelteovnsarbeidere, varmere, herdere, glødere og støperiarbeider, men man ekskluderte de i næringen 'produksjon av ikkejernholdig metaller' og bosatt nær aluminiumsverkene.

- Øvrige yrker innen elektroarbeid og næringen 'produksjon av elektriske apparater og materiell' lokalisert til steder med akkumulatorproduksjon.

- Industrilakkerer i næringen 'produksjon av transportmidler'.

- Glasshytte-arbeidere, ovnspassere, dekoratører, glasserere; øvrige yrker innen denne gruppen glass-, keramikk- og teglarbeid og bosatt nær glassverkene.

- Operatører i næringen 'produksjon av kjemiskteknisk produkter' bosatt på steder med malingproduksjon.
Fødselsutfall ble studert hos barn der mor eller far var kategorisert som høyt, middels og ikke blyeksponert. Hvis mor var blyeksponert hadde barnet økt risiko for nevralrørsdefekter og lav fødselsvekt. En dose-respons sammenheng ble sett mellom grad av blyeksponering for både lav fødselsvekt og kort svangerskapsvarighet. Barn av blyeksponerte fedre hadde ingen økt risiko for de utfallene som ble studert. Tvert imot hadde barna redusert risiko for lav fødselsvekt og for tidlig fødsel.

Tannlegeassistenter - nevralrørsdefekter

Flere artikler gir resultater på forekomst av nevralrørsdefekter hos barn av kvinnelige tannlegeassistenter, men resultatene av studiene er sprikende. Tannlegeassistenter kan ha vært yrkesmessig eksponert for teratogener, blant annet kvikksølv og røntgenstråling. Man forventet at kvikksølveksponering var redusert i løpet av perioden. Studien (27) sammenlignet forekomst av hjernemisdannelser hos tannlegeassistenters barn $(\mathrm{N}=5432)$ med de øvrige fødte. Syv av deres barn hadde nevralrørsdefekter som ga en ikke-signifikant øket odds ratio (1,41; CI 0,61-2,77). Ingen av tilfellene forekom etter 1985 .

\section{Jagerflyvere - kjønnsratio}

Anekdotiske opplysninger om redusert andel sønner hos flygere i forsvaret, ble støttet $\mathrm{i}$ to amerikanske studier fra 1961 og 1987, men ikke i en tysk studie fra 1976. I denne studien (28) brukte man FoB/MFR-data til å studere forholdet i Norge. Flygere i forsvaret ble identifisert på grunnlag av flygerutdanning og ansettelse i næringen 'forsvaret'. Flygerne var fedre til 65 barn hvorav 36,9\% var gutter. Sammenlignet med de øvrige fødte var dette en signifikant redusert ratio på 0,72 .

\section{Elektromagnetiske felt og fødselsutfall}

En amerikansk artikkel rapporterte redusert andel gutter blant barn med fedre i anodeproduksjon i aluminiumsindustrien. Dette initierte en norsk studie der hypotesen var at barn av foreldre eksponert for sterke statiske og ekstremt lavfrekvente elektromagnetiske felt (ELF) hadde avvikende kjønnsratio (29). ELFeksponerte ble identifisert på grunnlag av yrkes-, næringskode og bosted. Andel gutter i referansepopulasjonen var $51,4 \%$, mens man så en tendens til redusert andel gutter hos mannlige produksjonsarbeidere. Andelen var 50,4\% hos produksjonsarbeidere i aluminiumsverk, i mangnesiumverk $47,3 \%$, i jernverk $50,0 \%$, i nikkelverk 48,3\%, og i elektrisk kabelproduksjon med testing 47,2\%. Den samme tendensen kunne sees i den lille gruppen av kvinnelige produksjonsarbeidere i smelteverk der $45,1 \%$ av barna var gutter.

Datagrunnlaget i et doktorgradsarbeid (30) som omhandler helseeffekter av elektromagnetiske felt bygger dels på FoB/MFR. Et ekspertpanel laget en yrkesmatrise der eksponering for $50 \mathrm{~Hz}$ elektromagnetiske felt over $0,1 \mu$ Tesla ble gruppert (under 4 timer, 4-24 timer og over 24 timer per uke). Man observerte økt risiko for lav fødselsvekt og neonatal død både når mor og far var eksponert. Studien (31) viste økt risiko 
for spina bifida og klumpfot hvis mor var eksponert, og økt risiko for anencephali og kategorien "andre fødselsdefekter" dersom far var eksponert.

Klusteret av misdannelser knyttet til missiltorpedobåten Kvikk initierte en studie (32) av effekter av radiofrekvente elektromagnetiske felt. MFR-data med fødte fra 1976-1995 ble koblet til FoB fra 1980 og 1990. Et ekspertpanel kategoriserte fars yrkeseksponering for radiofrekvente elektromagnetiske felt (sannsynlig ikke eksponert, mulig eksponert og sannsynlig eksponert). Barn av eksponerte fedre hadde økt risiko for preterm fødsel. Ved middels eksponering var det øt risiko i kategorien "andre defekter".

\section{DISKUSJON}

\section{Hvor står vi i dag?}

På tross av optimismen som rådet for 20 år siden (33, 34) for at miljøårsaker til reproduksjonsskader skulle avdekkes og forebygges, har lite kommet ut av forskningen (35). Kogevinas et al. har i lederen Pesticides and congenital malformations - how many studies will it take to reach a conclusion? problematisert rundt dette (36). Forfatterne besvarer tittelspørsmålet med at det ikke er snakk om antall studier som må gjennomføres, men hva slags studier. I tillegg hevder de at man kanskje bør vente med nye studier til andre områder av biomedisinsk forskning har fått økt kunnskap om årsaker til medfødte misdannelser.

\section{Kvalitet i yrkesepidemiologiske studier - utfordringer}

Kvalitet i yrkesepidemiologiske studier er av stor betydning for resultatet. I håp om å komme frem til holdbare resultater $\mathrm{i}$ fremtidige studier har vi derfor store utfordringer. I Norge har vi gode muligheter til å selektere grupper ved hjelp av fødselsnummeret, eksempelvis kan man selektere kun de med samme yrkeskode $\mathrm{i}$ to på hverandre følgende folketellinger. Dette vil redusere feilklassifiseringen og øke datakvaliteten. Vi kan også bruke fødselsnummeret til å foreta kobling mellom flere registre.

Informasjonsskjevhet i studiene er en stor utfordring. Differensiell feilklassifisering er sjelden et problem i motsetning til for eksempel ikke-differensiell feilklassifisering av eksponering. Dette er et velkjent og nærmest uunngåelige problem når eksponeringsdata hentes fra administrative registre innsamlet for andre formål enn forskning. Ikke-differensiell feilklassifisering av eksponering vil nesten alltid føre til et mer konservativt risikoestimat slik at reell økt risiko kan bli oversett (37). Resultatskjevheter som skyldes feilklassifisering kan sannsynligvis reduseres ved at man $\mathrm{i}$ fremtiden tar i bruk data fra eksponeringsdatabaser.

Også feilklassifisering i MFR-data kan være et problem. Dette gjelder særlig for enkelte misdannelser. Som nevnt kan informasjon som MFR innhenter fra barnets innleggelser i neonatalavdelinger første leveår, bedre kvaliteten på klassifisering av misdannelser.
Feilklassifisering av misdannelser og andre utfall kan også ha andre årsaker enn kvalitet i MFR. Et eksempel er problemer knyttet til korrekt klassifisering og avgrensning av misdannelser. Misdannelser med samme morfologiske diagnose kan ha heterogene årsaksforhold, og misdannelser med ulik morfologi kan ha samme årsak (38).

Feilklassifisering av kovariater er også et problem i epidemiologiske studier. Fremfor å bruke retrospektive data på mors reproduksjonshistorie, har vi med MFR et godt utgangspunkt for å etablere longitudinelle filer med familien som analyseenhet. Dette gir muligheter for bedre data på mors reproduksjonshistorie enn om vi baserer forskningen på tverrsnittsstudier.

Tilfeldige funn og lav statistisk styrke er et kjent problem i epidemiologiske studier. Medfødte misdannelser forekommer sjelden, mens fødselsutfall som lav fødselsvekt, kort svangerskapslengde, aborter og perinatal død er hyppigere. Når man skal studere sammenheng mellom en konkret misdannelse og en yrkeseksponering blir gruppene ofte små. Til tross for at dette kan være studier der yrkeseksponering er godt kartlagt, kan den statistiske styrken være for lav til å kunne avdekke faktiske effekter. Imidlertid er det en styrke at vi selv i et lite land som Norge kan etablere store kohorter på grunn av koblingsmulighetene med fødselsnummer. Vi har med 40 års registrering i MFR unike sjanser til å studere fødselsutfall knyttet til yrkeseksponering hos foreldre og besteforeldre.

$\mathrm{Vi}$ vet lite om fosterets toleranse for ulike typer eksponering. Det er uavklart hvilke effekter en langvarig lavgradig eksponering gir i forhold til en kortvarig høy eksponering. Er en spesifikk eksponering i en kort, kritisk periode i fosterlivet av betydning for en spesifikk medfødt misdannelse? Kan en forvente ulike uønskete svangerskapsutfall fra en og samme eksponering? Ennå vet vi lite om dette.

\section{Enkelte fremtidsmuligheter}

Et problem med noen av de publiserte studiene er løst funderte hypoteser. Signifikante funn fra hypotesegenererende studier kan være resultat av tilfeldig variasjon. En raffinering av hypoteser som i større grad bygger på biologisk og mekanistisk forståelse og kunnskap, vil øke kvaliteten i fremtidige studier. Fremtidige studier bør også bygge på mekanistisk kunnskap og tidsaspektet, og om skade involverer mors eggcelle (fremtidige eller modnende i konsepsjonssyklus), fars sædcelle (stamcelle eller modnende spermie), eller teratogen virkning.

\section{Eksponeringsdatabaser}

Finland har en godt utbygd database over biologiske målinger av kjemisk eksponering i arbeidslivet. Denne databasen er utgangspunkt for flere yrkesepidemiologiske studier av spontanabort og medfødte misdannelser, for eksempel Markku Sallméns doktorgradsarbeid (39). Også i Norge bør det være mulig å utnytte eksisterende kilder med biologiske måledata eller ekspone- 
ringsdata. En slik database er EXPO (40). Databasen ble opprinnelig etablert i samarbeid med Arbeidstilsynet, og er etablert ved Statens arbeidsmiljøinstitutt (STAMI). EXPO inneholder alle yrkeshygieniske målinger og analyser utført av STAMI siden 1984, og inneholder i dag måleresultater fra mer enn 120000 prøver fra ca. 5000 bedrifter. Data i EXPO omfatter:

- Næringsgruppe

- Et eget utviklet kodesystem for arbeidsbeskrivelser

- Arbeidsoperasjon og arbeidssted

- Fritekst med arbeidsbeskrivelse

- Navn og fødselsdato (ikke personnummer)

- Miljøfaktorer med beskrivelser av kilden i 4 eksponeringsnivåer

- Analyseresultat

Noen av prøvene er tatt etter pålegg fra myndigheter, andre er rutineprøver. I epidemiologiske studier bør det derfor vurderes nøye hvor representative prøvene er og hvilke prøvetakingsstrategier som er fulgt.

Nye data fra MFR - mors yrke

Dersom mor har samtykket, har MFR informasjon om mors yrke som fritekst fra 1998. Av økonomiske grunner er koding ikke iverksatt ennå. Slike opplysninger vil være verdifulle både for forskning og overvåkning, og det er å håpe at datakodingen kan bli gjennomført.

Data om yrket fra FoB $i$ dag

Statistisk sentralbyrå har tatt i bruk nytt EU-tilpasset kodeverk for både yrke, næring og utdanning. Fortsatt er ikke den norske yrkeskodeverket komplett, blant annet mangler koder i helseforetak, i kommunal- og fylkeskommunal sektor. Dette vil derimot bli bedre etter hvert, og i motsetning til tidligere vil opplysninger om yrke være tilgjengelig for kobling hvert år (Personlig meddelelse fra førstekonsulent Britt Elin Bråten, Seksjon for befolkningsstatistikk, Statistisk sentralbyrå i februar 2007). Alle arbeidstakerforhold tildeles i dag en 7-sifret yrkeskode, men frem mot publisering av yrkesstatistikk, vil det gjøres kvalitetsundersøkelser og vurderinger av hvor detaljert man kan oppgi dette (41).

Data fra Mor og Barn-studien (MoBa) - MFR

Store kohortstudier, som MoBa-studien, innhenter opplysninger både om yrke og yrkeseksponering, og vil være et godt utgangspunkt for videre forskning dersom store eksponeringsgrupper skal studeres. Studiens mål er å følge 100000 svangerskap fra 16.-17. svangerskapsuke. Kvinnene som deltar får i tillegg tilsendt spørreskjema i uke $22 \mathrm{og} 30$. Etter fødselen får mor tilsendt skjema når barnet er 6,18 og 36 måneder. Far deltar med ett skjema. Blodprøver tas av både mor og far ved tid for ultralyd, i tillegg avgir mor en urinprøve. Det tas en ny blodprøve av mor ved fødsel og en navlestrengsblodprøve av barnet. Yrkesinformasjonen i MoBa er oppgitt som fritekst, den er ennå ikke kodet og økonomien avgjør om det vil bli gjort. Opplysningene i MoBa-studien er også tilkoblet MFRdata.
MoBa-studien inkluderer mange spørsmål om den gravides egen oppfatning av fysisk, kjemisk og psykososialt arbeidsmiljø som kan utnyttes i yrkesepidemiologiske studier. Biologiske prøver i MoBa-studien gir i prinsippet også mulighet for å bruke biomarkører for eksponering. Mangelen på yrkesopplysninger kan, som for MFR, kompenseres på andre måter, for eksempel ved kobling til andre datakilder. Alternativt kan man gjennomføre pasient-kontrollstudier der yrket bare blir kodet for foreldre til barn med misdannelser og for kontrollgruppen.

\section{Data fra Statens Helseundersøkelser}

Flere helseundersøkelser er gjennomført i norske fylker de senere år (42). I noen inngikk utvalgte aldersgrupper, mens hele den voksne befolkningen ble invitert til å delta $\mathrm{i}$ andre. Ved flere av helseundersøkelsene ble det tatt blodprøver, og ved noen er det stilt spørsmål knyttet til yrke. Så langt er lite av disse opplysningene brukt til kobling mot MFR i yrkesepidemiologiske studier. I flere av fylkesundersøkelsene har man også ungdomsundersøkelser som kan være aktuelle for kobling mot MFR i den grad de blir fulgt opp i voksen alder.

\section{Data tilgjengelig for gen-arbeidsmiljø-} interaksjonsstudier?

I pasient-kontrollstudien SAM (svangerskap, arv og miljø), var pasientgruppen barn med leppe-, kjeve- og ganespalte. Gruppen besto av ca. 600 barn der kontakt ble etablert gjennom de plastikkirurgiske avdelingene ved Rikshospitalet og Haukeland Universitetssykehus. En tilfeldig valgt kontrollgruppe besto av ca. 1500 barn uten leppe- kjeve- eller ganespalte. Alle fylte ut et omfattende spørreskjema som også registrerte yrkeseksponering hos mor og avga blodprøver. Dette prosjektet var et samarbeid mellom MFR og National Institute of Enviromental Health Sciences (NIEHS), North Carolina $(43,44)$. Et oppsett som dette ville være mulig for studier der man ønsker å studere interaksjoner mellom gener og arbeidsmiljø.

Data knyttet til bestemors arbeidsmiljø

Dyrestudier (45) har vist at eksponering for reproduksjonstoksiske agens under drektigheten kan føre til redusert fertilitet hos avkommet. Studier har også vist at dersom mor røykte da hun var gravid, kan dette føre til infertilitetsproblemer hos barna en generasjon senere (46). Slike studier kan la seg gjennomføre i Norge ved hjelp av generasjonsopplysninger fra MFR, opplysninger om bestemors yrkeseksponering i forbindelse med bestemors graviditet (det vil si mors prenatale eksponering) og fødselsutfall hos barnebarna.

\section{KONKLUSJON}

Til tross for problemer knyttet til yrkesepidemiologiske reproduksjonsstudier, har vi i Norge gode muligheter til å gjennomføre slike studier. Norske systemer for overvåkning av arbeidsliv og helse, deriblant MFR, er i stadig utvikling, og kunnskap innen bioteknologis- 
ke metoder er økende. Studier i samarbeid med de andre nordiske land der vi tar i bruk det vi får av ny kunnskap på dette feltet, er en fremgangsmåte for videre forskning.

Utfordringer ved fremtidige yrkesepidemiologiske studier er å utnytte de muligheter som finnes for å øke kvalitet og validitet. I fremtiden kan det være tilgjen- gelig flere kilder og kilder av høyere kvalitet som inneholder yrkeseksponeringsdata, studier kan bli gjennomført der gen-arbeidsmiljø interaksjoner inkluderes, samt studier med opplysninger om arbeidsmiljø i flergenerasjonsstudier. Slike og andre tilnærminger kan bidra til økt kunnskap innen dette feltet i fremtiden.

\section{REFERANSER}

1. Ny forskrift MFR. http://www.lovdata.no/cgi-wift/ldles?doc=/sf/sf/sf-20011221-1483.html. 2007.

2. Irgens A, Irgens LM, Reitan JB, Haldorsen T, Tveten U. Pregnancy outcome among offspring of airline pilots and cabin attendants. Scand J Work Environ Health 2003; 29: 94-99.

3. Kristensen P, Irgens LM, Daltveit AK, Andersen A. Perinatal outcome among children of men exposed to lead and organic solvents in the printing industry. Am J Epidemiol 1993; 137: 134-144.

4. Bjerkedal T, Egenæs J. Video display terminals and birth defects. I: Knave B, Widebäck P-G, red. Work with Video Display Units. Selected Papers from the International Scientific Conference on Work with Display Units, Stockholm, Sweden, May 12-15, 1986. Amsterdam: North-Holland, 1987: 111-114.

5. Ahlborg G Jr, Bjerkedal T, Egenaes J. Delivery outcome among women employed in the plastics industry in Sweden and Norway. Am J Ind Med 1987; 12: 507-517.

6. Olsen J, Hemminki K, Ahlborg G, Bjerkedal T, Kyyronen P, Taskinen H, et al. Low birthweight, congenital malformations, and spontaneous abortions among dry-cleaning workers in Scandinavia. Scand J Work Environ Health 1990; 16: 163-168.

7. Nordby K-C. Exposure to selected natural and man-made toxic substances in agriculture and their associations with cancers and reproductive outcomes in farmers' families (Doktorgradsavhandling). Oslo: University of Oslo, 2006.

8. Kristensen P. Perinatal health and cancer in farmers' offspring: a register linkage study on the occurrence of adverse outcomes and the influence of risk factors in the farm environment (Doktorgradsavhandling) . Norsk Epidemiologi 1997; 7: 1-41.

9. Kristensen P, Irgens LM, Andersen A, Bye AS, Sundheim L. Gestational age, birth weight, and perinatal death among births to Norwegian farmers, 1967-1991. Am J Epidemiol 1997; 146: 329-338.

10. Kristensen P, Irgens LM, Andersen A, Bye AS, Sundheim L. Birth defects among offspring of Norwegian farmers, 1967-1991. Epidemiology 1997; 8: 537-544.

11. Nordby K-C, Kristensen P. Adverse effects of mycotoxins among Norwegian farmers, with reference to endocrine disrupting effects. I: Grotmol T, Bernhoft A, Eriksen GS, Flaten TP, red. Endocrine disrupters. Proceedings from a symposium held at the Norwegian Academy of Science and Letters, Oslo, 13-14 October 2005. Oslo: The Norwegian Academy of Science and Letters, 2006: 145-152.

12. Kristensen P, Irgens LM, Bjerkedal T. Environmental factors, reproductive history, and selective fertility in farmers' sibships. Am J Epidemiol 1997; 145: 817-825.

13. Skjaerven R, Wilcox AJ, Lie RT, Irgens LM. Selective fertility and the distortion of perinatal mortality. Am J Epidemiol 1988; 128: 1352-1363.

14. Kristensen P, Andersen A, Irgens LM. Hormone-dependent cancer and adverse reproductive outcomes in farmers' families - effects of climatic conditions favoring fungal growth in grain. Scand J Work Environ Health 2000; 26: 331-337.

15. Nordby KC, Irgens LM, Kristensen P. Immunological exposures in Norwegian agriculture and pre-eclampsia. Paediat Perinat Epidemiol 2006; 20: 462-470.

16. Kristensen P, Irgens LM. Multiple pregnancies among women engaged in agriculture in Norway, $1967-91$. Norsk Epidemiologi 1999; 9: 57-64.

17. Nordby KC, Andersen A, Irgens LM, Kristensen P. Indicators of mancozeb exposure in relation to thyroid cancer and neural tube defects in farmers' families. Scand J Work Environ Health 2005; 31: 89-96.

18. Kristensen P, Irgens LM. Clusters of anophthalmia: no link with benomyl in Norway (Letter). BMJ 1994; 308: 205-206.

19. Kristensen P, Irgens LM. Maternal reproductive history: a registry based comparison of previous pregnancy data derived from maternal recall and data obtained during the actual pregnancy. Acta Obstetr Gynecol Scand 2000; 79: 471-477.

20. Bjerkedal T. Yrke og fødsel: En undersøkelse over betydningen av kvinners yrkesaktivitet for opptreden av fosterskader. Rapporter 80/9. Oslo: Statistisk Sentralbyrå, 1980. 
21. Bjerkedal T. Occupation and outcome of pregnancy: a population-based study in Norway. I: Marois M, red. Prevention of Physical and Mental Congenital Effects, Part B: Epidemiology, Early Detection and Therapy, and Environmental Factors. New York: Alan R. Liss, 1985: 265-268.

22. Irgens Å, Krüger K, Skorve AH, Irgens LM. Yrke og reproduksjonsutfall. Bergen: Yrkesmedisinsk avdeling, Haukeland Universitetssykehus, 1996.

23. Irgens A, Kruger K, Skorve AH, Irgens LM. Birth defects and paternal occupational exposure. Hypotheses tested in a record linkage based dataset. Acta Obstet Gynecol Scand 2000; 79: 465-470.

24. Olshan AF, Schnitzer PG. Paternal occupation and birth defect. Male Mediated Developmental Toxicity. New York: Plenum Press, 1994.

25. Nordman $\mathrm{CH}$. Nordiska expertgruppen för hygienisk gränsvärdesdokumentation. Organiskt bly. Arbeta \& Hälsa 1979; 24: 1-55.

26. Irgens A, Kruger K, Skorve AH, Irgens LM. Reproductive outcome in offspring of parents occupationally exposed to lead in Norway. Am J Ind Med 1998; 34: 431-437.

27. Irgens Å, Krüger K, Skorve AH, Irgens LM. Har tannlegeassistenter økt risiko for å få barn med hjernemisdannelser? Nor Tannlegeforen Tid 1997; 17: 856-858.

28. Irgens $\AA$, Krüger K, Skorve AH, Irgens LM. Male proportion in offspring of military air pilots in Norway. Norsk Epidemiologi 1999; 9: 47-49.

29. Irgens A, Kruger K, Skorve AH, Irgens LM. Male proportion in offspring of parents exposed to strong static and extremely low-frequency electromagnetic fields in Norway. Am J Ind Med 1997; 32: 557-561.

30. Blaasaas KG. $50 \mathrm{~Hz}$ magnetic fields and adverse pregnancy outcomes; Effects of residential and occupational exposures assessed in register based studies. National Institute of Occupational Health, Norwegian Radiation Protection Authority, Medical Birth Registry of Norway, 2003.

31. Blaasaas KG, Tynes T, Irgens A, Lie RT. Risk of birth defects by parental occupational exposure to $50 \mathrm{~Hz}$ electromagnetic fields: a population based study. Occup Environ Med 2002; 59: 92-97.

32. Mjoen G, Saetre DO, Lie RT, Tynes T, Blaasaas KG, Hannevik M, Irgens LM. Paternal occupational exposure to radiofrequency electromagnetic fields and risk of adverse pregnancy outcome. Eur J Epidemiol 2006; 21: 529-535.

33. Whorton MD. Adverse reproductive outcomes - the occupational-health issue of the 1980s. Am J Public Health 1983; 73: 15-16.

34. Lockey JE, Lemasters GK, Keye WR Jr. Reproduction: the new frontier in occupational and environmental health research. New York: Alan R. Liss, 1984.

35. Kristensen P. Parental exposure, adverse pregnancy and offspring effects - perspectives in developmental epidemiology. Scand J Work Environ Health 1999; 25: 541-549.

36. Kogevinas M, Sala M. Pesticides and congenital malformations - how many studies will it take to reach a conclusion? Scand J Work Environ Health 1998; 24: 445-447.

37. Kristensen P. Bias from nondifferential but dependent misclassification of exposure and outcome. Epidemiology 1992; 3: 210-215.

38. Khoury MJ, Moore CA, James LM, Cordero JF. The interaction between dysmorphology and epidemiology methodologic issues of lumping and splitting. Teratology 1992; 45: 133-138.

39. Sallméns M. Fertility among workers exposed to solvents or lead (Doktorgradsavhandling). Helsinki: Finnish Institute of Occupational Health, 2000.

40. EXPOdatabasen. http://www.stami.no/NOA/Om_NOA/NOAs_kilder/?module=Articles;action=Article.public Show;ID=2546. 2007.

41. Yrkeskoding. http://www.ssb.no/emner/06/90/notat_200170/notat_200170.pdf. 2007.

42. Statens helseundersøkelser. http://www.fhi.no/eway/default.aspx?pid=233\&trg=MainArea_5661\&MainArea 5661=5565:0:15,1213:1:0:0:::0:0. 2007 .

43. Wilcox AJ, Lie RT, Solvoll K, Taylor J, McConnaughey DR, Abyholm F, Vindenes H, Vollset SE, Drevon CA. Folic acid supplements and risk of facial clefts: national population based case-control study. BMJ 2007; 334: 464.

44. Jugessur A, Wilcox AJ, Lie RT, Murray JC, Taylor JA, Ulvik A, Drevon CA, Vindenes HA, Abyholm FE. Exploring the effects of methylenetetrahydrofolate reductase gene variants C677T and A1298C on the risk of orofacial clefts in 261 Norwegian case-parent triads. Am J Epidemiol 2003; 157: 1083-1091.

45. Kristensen P, Eilertsen E, Einarsdottir E, Haugen A, Skaug V, Ovrebo S. Fertility in mice after prenatal exposure to benzo[a]pyrene and inorganic lead. Environ Health Perspect 1995; 103: 588-590.

46. Weinberg CR, Wilcox AJ, Baird DD. Reduced fecundability in women with prenatal exposure to cigarette smoking. Am J Epidemiol 1989; 129: 1072-1078. 